
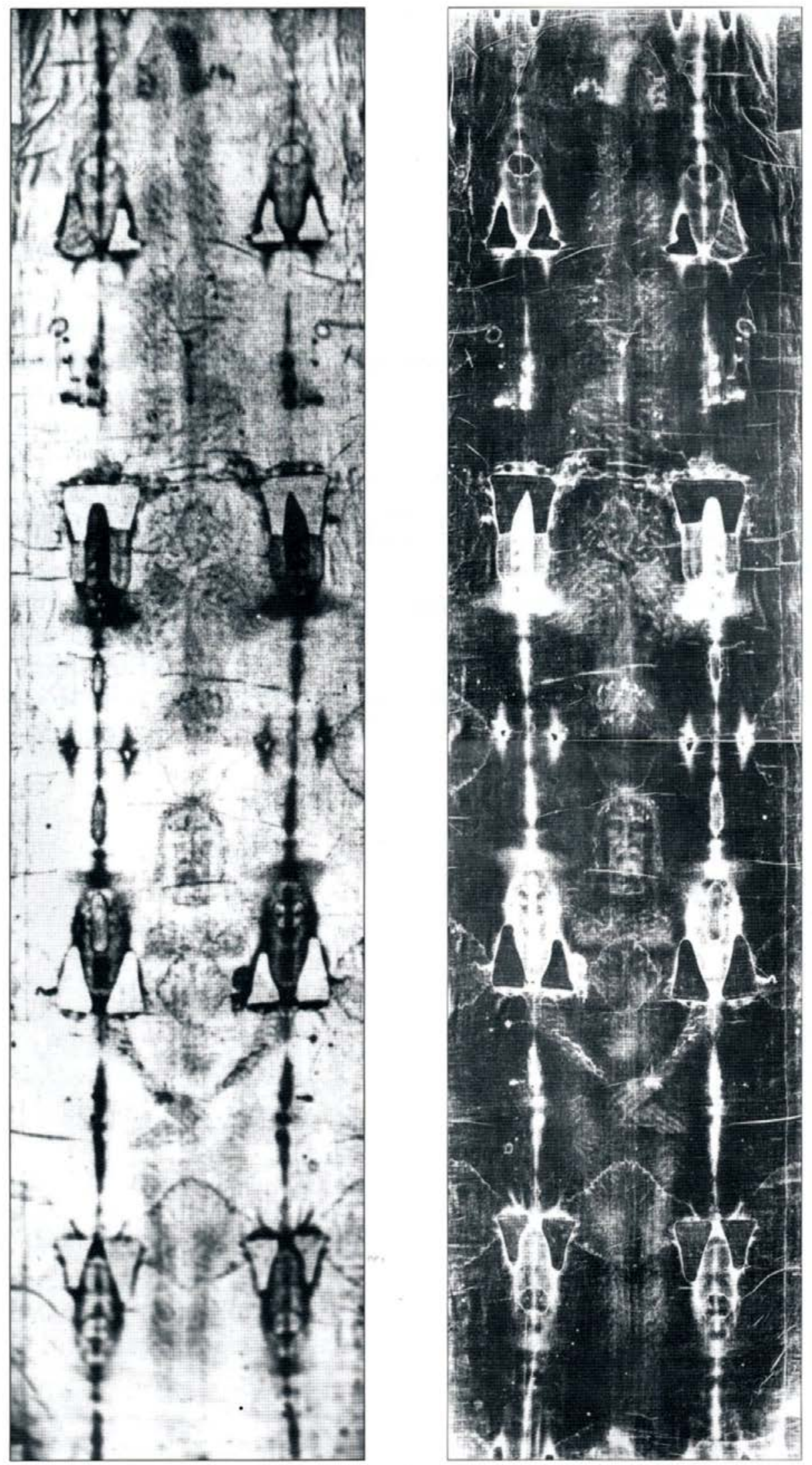

Fig. 1. Positive and negative photographs of the Shroud of Turin. Note features described in the text. 


\title{
A CHEMICAL INVESTIGATION OF THE SHROUD OF TURIN
}

\author{
JOHN H. HELLER AND ALAN D. ADLER
}

\begin{abstract}
Microchemical testing of materials recovered on "sticky" tape samples taken from the Shroud of Turin was undertaken. The Shroud is a linen cloth, bearing the image of what appears to be a crucified man with the classical stigmata of Christ's crucifixion. The presence of whole blood was established by detection of heme derivatives, bile pigments, and proteins. Although iron in several forms is found over the whole cloth its distribution is shown to be accounted for by natural processes rather than as an added pigment. There is no chemical evidence for the application of any pigments, stains, or dyes on the cloth to produce the image found thereon. The chemical differences between image and nonimage areas of the cloth indicate that the image was produced by some dehydrative oxidative process of the cellulose structure of the linen to yield a conjugated carbonyl group as the chromophore. However, a detailed mechanism for the production of this image, accounting for all of its properties, remains undetermined.
\end{abstract}

Since 1977 an American scientific team has been extensively investigating the Shroud of Turin. $^{1-3}$ This $4.36 \times 1.10 \mathrm{~m}$. linen cloth, now kept as a relic at the Cathedral of St. John in Turin, Italy, has had a long and controversial history, ${ }^{4-7}$ as it is alleged to be the authentic burial shroud of Jesus Christ. It bears both a complete head-to-head, front and back, straw yellow colored "reversed" image of what appears to be a crucified man with "blood-colored" wounds and scourge marks in accordance with Biblical description in the four Gospels. ${ }^{1-7}$ The Shroud first came to historical attention in 1356 in France and was often displayed. Subsequently, it was kept in a silver box. A fire in 1532 melted portions of this box and molten silver burned its way through the folded cloth leaving scorched areas which were later repaired..$^{1-7}$ The fire was extinguished with water which penetrated the holes in the casket, making large water stains on the cloth. Refer to Figure 1 for these details.

In 1898 Secondo Pia observed ${ }^{17}$ that the image is "reversed" in that a photographic negative gives a positive image. When these and later photographs of the image were examined by a VP-8 image analyzer, ${ }^{8-9}$ startling three dimensional images of a man were obtained. These are the graphic results of a one-to-one mapping function relating image density to cloth-body distance. ${ }^{9}$ The method for creating this reversed image with such striking three dimensional characteristics is unknown. ${ }^{8-16}$

A prior investigator ${ }^{17-19}$ has published a microscopic evaluation of the samples from the Shroud. This study claims that the body image is due to an iron oxide 
earth pigment bound with an age yellowed animal binder that had been painted onto the cloth. ${ }^{17,18}$ The blood marks are attributed to a mixture of iron oxide pigments and vermillion in this same binder. ${ }^{19}$ In light of our chemical findings we disagree with these conclusions.

We have carried out a complete analysis of the fibrils and particles found on the Shroud samples. The fibrils and particles seen are of several types (cf. Tables 1 and 2). There are (a) the clear to pale yellow background fibrils (non-image) of the cloth which bear no image or blood stains. There are (b) yellow fibrils (body image) which are responsible for the body image and, also, (c) golden yellow coated fibrils adjacent to heavy blood flows. (d) "Blood" stained fibrils (blood image) and a variety of variously colored particles (cf. Table 2) are also seen. (e) Elongated dark scorch marks from the fire in 1532 frame the entire length of the images thus providing scorched fibrils and (f) extensive well-defined water stains incurred in extinguishing this fire partially overlap the body image itself providing "water stained" samples. (g) Linen patches were used to repair the larger scorch areas, and backing cloths have since been sewn to the entire length of the cloth to further strengthen and protect the relic, providing various types of other adventitious fibrils. See Figure 1 for a photographic reproduction of the Shroud.

While scientific testing could readily establish if this artifact is a "forgery", e.g., a painting, it should be noted that it cannot establish unequivocally that it is "authentic". The best that such studies can do is to frame and test hypotheses that would demonstrate that it is definitely a forgery or that the results are not inconsistent with a position accepting it as authentic should one so choose to believe. Several of the group's investigations, mainly physical, have already been reported. ${ }^{8-16}$ However, questions such as the chemical nature of the blood and the image are also susceptible to direct chemical testing. The purpose of this paper is to report such an investigation.

\section{Experimental}

Using a special Mylar tape with a proprietary toluene soluble hydrocarbon polymer adhesive (supplied by 3M Corp.), Rogers removed specimens from the surface of the cloth (fibrils and particles) from identified locations by a "sticky tape" sampling technique for chemical analysis.

Each tape was about $5 \mathrm{~cm}^{2}$ in area and 36 such samples were taken. The identification code and Shroud location. of the samples that we received for study are given in Table 1. These tape samples were later affixed to microscope cover glasses by a prior investigator ${ }^{17}$ and we received them in this form. Of the 22 samples received, 6 were blood image samples, 2 were body image adjacent to blood marks, 2 were body image (only) samples, 3 were water stain/body image samples, 1 was non-image, 4 were water stain/non-image, and also 2 scorch, 1 patch, and 2 backing cloth samples. 3BB is a water stain/body image sample adjacent to blood and has been counted twice in the above designations.

Prior to chemical testing, the tape samples were examined microscopically. A Zeiss Photomicroscope III, (both transmission and reflection mode), a Bausch and Lomb model LI polarizing microscope, Leitz Ortholux, and a Nikon PFM 
phase contrast microscope were used to locate and characterize the classes of objects of interest. Tungsten sources and xenon arcs were employed. The Mylar tape was found to be optically anisotropic with its optic axes aligned with the edges of the tape and is therefore a "crystalline" form of this polyethylene terephthalate polymer (glass transition point $=80^{\circ} \mathrm{C}$ ). Therefore, polarization studies were carried out on specimens only after their removal from the tape and adhering adhesive to prevent misinterpretation due to the optical properties of the tape itself.

The microscopic survey revealed that there were a large variety of fibrils and particulates present in the samples along with occasional assorted "incidental" debris found in limited quantities such as insect parts, pollen, spores, wax, modern synthetic fibrils, red and blue silk, wool, and flair tip pen dye marks (due to a previous investigator ${ }^{17}$ ). The red and blue silk fibrils appear to be from backing cloths and borders and are present in almost every sample. This illustrates that there has been transposition of materials from one area of the cloth to another, as it was folded and unfolded numerous times through the centuries (as first noted by John Jackson). Therefore, we have arbitrarily set a minimum threshold of 15 specimens of a particular set of characteristics to constitute a class of fibrils and particles typical of a specific location on the cloth. These classes, their "locations", and microscopic characteristics are given in Table 2. The fibrils range in color from pale yellow to dark brown. Some are coated, others uncoated. The particles range in color from yellow-orange through red to black. Some of the red particles are birefringent, while others are not.

To prepare a specimen for testing, the portion of tape containing it was excised by scalpel from the sample. It was then washed free of the tweezer-held tape with toluene into a spot plate well. The adhesive was then removed by repeated washings with toluene. The wash toluene was removed by micropipette or by sorption into small pointed strips of filter paper while the specimen was held in place with a glass needle. Final removal of the adhesive could be tested with short wave UV irradiation, under which the adhesive gives a bluish-white fluorescence. All of the above operations were carried out under a Bausch and Lomb Stereozoom binocular microscope. White spot plates were used for colorimetric tests, black spot plates for fluorimetric tests, and transparent well slides for those tests where it was desired to examine the results under the microscopes cited above at magnifications higher than $30 \mathrm{X}$.

The majority of the linen fibrils ranged from $10-15 \mu \mathrm{m}$ in diameter. They were from $40 \mu \mathrm{m}$ to several $\mathrm{mm}$ in length. The silk fibrils were longer and some were almost one $\mathrm{cm}$ in length. Most of the red particulates ranged from submicron to about $3 \mu \mathrm{m}$, and the birefringent red particulates from $0.7 \mathrm{pm}$ to about $1 \mathrm{pm}$ diameter. These particulates were therefore too small for accurate quantitative determination of their optical parameters by the standard methods. ${ }^{20-}$ 23 Highly variable results were obtained even for refractive index measurements by immersion methods. However, when a red non-birefringent coated fibril and a birefringent red particulate coated fibril were compared side by side immersed in benzene (index of refraction $=1.50$ ), the Becke line movements were in opposite directions. Therefore, the refractive index of the non-birefringent red particles is 
less than 1.5, while it is greater than 1.5 for the birefringent red particles, indicating that they are quite different materials. As shown below, the birefringent materials are $\mathrm{Fe}_{2} \mathrm{O}_{3}$ while the non-birefringent are proteinaceous and therefore the refractive index characteristics seen are those that might be expected.

The globs vary in size from about $5 \mu \mathrm{m}$ to $50 \mu \mathrm{m}$ in linear dimensions. The opaque black particles vary from about $25 \mu \mathrm{m}$ to $100 \mu \mathrm{m}$ in linear dimensions. Therefore, assuming densities between approximately 1 (protein and cellulose) to $3 \mathrm{gm} / \mathrm{cm}^{3}$ (iron oxides), we see that the masses of individual specimens range from a few nanograms for the smallest objects up to micrograms for the largest.

Once separated, the specimens were tested by standard microchemical techniques. ${ }^{24-27}$ When necessary, digestions were carried out with a heat lamp. Chamot and Mason ${ }^{24}$ have indicated that the sensitivity of many microchemical tests can be enhanced by saturating a sorbent fiber in the reagent and introducing it into the test solution of the unknown as the color change remains "concentrated" on the test surface. We found the reverse procedure, i.e., a fibril unknown introduced into concentrated test reagent solution, also enhanced sensitivity. All tests of unknowns were run side by side with controls; a blank reagent control, a known "Spanish linen" fibril control (see below), or a solution set at the lowest level of positive detection. All chemicals used were reagent grade. (Most test reagents were obtained from G. Frederick Smith, inorganics from Fisher Scientific, organics from either Aldrich or Eastman Kodak, and specialty biochemicals from Sigma.)

A number of specific $1 \mathrm{~cm}^{2}$ linen controls were prepared from a 300 year old Spanish linen sample used previously in our testing. ${ }^{14}$ These controls are listed in Table 3. Fibrils of this Spanish linen were also used as the "known" controls in the manner referred to above for tests for specific ions, functional groups, or substances. Samples of Coptic (circa 350 A.D.) and Pharaonic (circa 1,500 B.C.) burial linens supplied to us by Professor G. Riggi of Turin were also used as controls.

It had been considered that the linen of the Shroud might have been treated with extracts of Saponaria officinalis. ${ }^{28}$ Specimens of this plant were identified ${ }^{29}$ and gathered locally just prior to blooming and extracted with $1 \% \mathrm{NaOH}$, and the extracts were then used to prepare Spanish linen Saponaria treated controls. It was observed that samples of such Saponaria treated cloth and, also, fibrils from it, after being twice rinsed with distilled water immediately turn deep brown on treatment with concentrated sulfuric acid, thereby providing a simple test for such Saponaria treatment.

In the process of mordanting and/ or weighting textiles various metal oxides, e.g., Cr, Sn, Fe, $\mathrm{Al}$, etc., are precipitated and affixed onto the cloth. ${ }^{30,31}$ Thus, an earlier method of producing "mineral khaki" was by impregnating linen or cotton cloth with solutions of iron salts, precipitating iron hydroxides onto and into the fibers with alkali, and then dehydrating, producing iron oxide particulates "fixed" to the cloth. ${ }^{32}$ We therefore also prepared such iron oxide "khakied" Spanish linen controls to test various postulates and to compare with Shroud specimens. 


\section{Results}

Proteins and heme derivatives - We have previously reported ${ }^{14}$ spectroscopic and chemical tests on the "shards" (replica casts which had broken off "blood" coated fibrils) and the nonbirefringent red coated fibrils, indicating the presence of blood materials on the Shroud. This previous chemical test consisted of dissolving the "blood" material in $97 \%$ hydrazine, while simultaneously reducing any presumptive ferric porphyrins present, splitting out the ferrous iron with concentrated formic acid, and then fluorimetrically detecting any porphyrins by their characteristic red fluorescence excited under long wave UV. Controls showed this test was sensitive to about one ng of methemoglobin for the dark-adapted eye. We have since confirmed a similar positive result on the larger, redder orange globs. However, none of the brown globs reacted, as might be expected if they represent partially charred blood materials. If the shards are barely covered, i.e., microspotted with a film of hydrazine, they slowly dissolve and give a characteristic pink hemochromagen-like color. ${ }^{33}$ Further, if the shards are similarly treated with $1 \mathrm{M} \mathrm{NH} \mathrm{NH}_{4} \mathrm{OH}$ solution saturated with $\mathrm{KCN}$, a characteristic cyanmethemoglobin type color $^{33}$ slowly develops on the surface. Similar hemochromagen and cyanmethemoglobin results can be obtained on the red coated fibrils, but not on any of the brown globs as again would be expected for partially charred hemeprotein materials. These results demonstrate, in our opinion, that the shards and red coated fibrils contain heme derivatives, thus corroborating our earlier results in concluding that the "blood" marks were in fact composed of blood.

In addition, we tested for heme breakdown products, i.e., bile pigments such as bilirubin, with Erlich's reagent ${ }^{34,} 35$ using the method of Jendrassik. ${ }^{36}$ For these purposes we employed the commercially available American Monitor "525" bilirubin test kit. Using the same microspotting technique as described above, characteristic blue azobilirubin colors could be positively detected in reflected light on the surfaces of the olive colored shards, the orange globs, and, also, weakly on the more orange colored red coated fibrils. The test color was sensitive to acid, turning a paler purple, and was discharged by 10 minutes of short wave UV light as is characteristic of this color test. ${ }^{35}$ In the previous spectral work ${ }^{14}$ it was noted that a peak does appear both in the whole cloth reflection studies and in microspectrophotometry of the tape samples at about $450 \mathrm{~nm}$. This is quite typical of bilidienes ${ }^{33}, 37$ and similar bile pigment structures, thus further indicating their presence on the Shroud itself in the "blood" image areas by both chemical test and spectroscopy.

There are a wide variety of tests available for proteins. Hydrolysis and detection of the formed amino acids by reaction with ninhydrin is quite sensitive. ${ }^{38}$ However, we observed that the $\mathrm{Ca}^{+2}$ and $\mathrm{Fe}{ }^{+3}$ levels found on the Shroud interfere with the color reaction (Ruhmann's purple) when this method was tested with controls. Amido black is frequently used as a general histological protein stain. ${ }^{39}$ It has been specifically used to detect the presence of proteins in some paint media ${ }^{40}$ and was employed as such by McCrone. ${ }^{18}$ However, we found that it also strongly stained pure cellulose (viscose rayon), and even more strongly stained the heat treated and scorched Spanish linen controls. The stain was not 
removed from these controls by treatment with proteases (trypsin, chymotrypsin, carboxypeptidase and lysozyme at $\mathrm{pH}$ 8.4). However, control Spanish linen fibrils impregnated with protein, stained with amido black and then treated with proteases returned the fibril color to the unstained condition within 20 minutes. These two tests show that amido black staining is not due to trace protein impurities in the linen, but due to the cellulose itself accepting the dye. We therefore felt that amido black was an unreliable test for protein outside the blood areas as it reacts similarly to other basic dyes, e.g., methylene blue, in staining surface oxidized cellulosic materials. The Coomassie Brilliant Blues have also been used in a similar fashion to amido black. ${ }^{41}$ In our tests they behaved in the same way as amido black and they therefore were rejected for similar reasons. These dyes stain strongly as they react with the cellulosic carboxyl groups present (see below).

As neither of these dyes are metachromatic, i.e., do not change color on reaction, but only adsorb onto the sample surface, we used Bromothymol Blue ${ }^{42,43}$ which does show a color change on interaction with protein. However, this proved only sensitive to the $1.0 \mu \mathrm{g}$ level in control tests. Similarly, the standard Biuret-Lowry test ${ }^{44}$ also, only proved sensitive to the 0.1 $\mu \mathrm{g}$ level in our control test conditions. As Bromcresol Green is also metachromatic and considered selective for albumin (cf. e.g., Albustix), we tested it and found that it could detect to the $0.1 \mu \mathrm{g}$ level for albumin under these conditions. The best suited protein reagent tested was fluorescamine. ${ }^{46}$ While specific for primary amino groups, it has been reported to detect one ng of protein ${ }^{46}$ by the generation of a characteristic green fluorescence under long wave UV. Control tests confirmed that it would do so under our test conditions.

Positive Bromcresol Green tests indicating albumin could be obtained for the larger, deeper yellow orange globs and also for the golden yellow ("serum") coated fibrils. Thus, this indicates that blood constituents other than hemeproteins are present in the blood areas. Similar albumin positive tests were also found in areas adjacent to the blood, e.g., the lance wound area. Elsewhere, expressed "serum", apparently due to clot retraction, is noted as might be expected if the wounds truly represent clotted images as proposed by Barbet. ${ }^{5}$

Positive fluorescamine tests were obtained on both the red and golden yellow coated fibrils, on the shards, and on both the orange and brown globs. The fluorescamine tests were definitely negative on all fibrils away from blood areas. This specifically includes yellow (body image) fibrils and the birefringent red particulate coated fibrils (these are found primarily in the water stain margins). Thus, protein is only found associated with "blood" areas and is definitely not present as a "pigment binder" in the body image areas above the nanogram level. Therefore, age-yellowed protein materials cannot account for the image as has been suggested. ${ }^{18}$

One further direct and specific test was carried out for proteins, namely, the effect of proteolytic enzymes. For these purposes a fresh concentrated mixture of trypsin, chymotrypsin, carboxypeptidase and lysozyme in $\mathrm{pH} 8.4$ buffer was employed. Within a half hour this solution completely "dissolved" the nonbirefringent red particulate coated fibril coatings, leaving no particulate residues. 
This further indicates that these particulates are blood and not $\mathrm{Fe}_{2} \mathrm{O}_{3}$ impregnated protein binder. This protease treatment also removes the golden yellow coating from the golden yellow fibrils, corroborating their identification as "serum" coated fibrils. Interestingly, fibrils freed of their coatings using this technique closely resemble the non-image fibrils when viewed under phase contrast. The protease solution also dissolved the shards, the orange globs, and the brown globs (leaving the small dark embedded particulates, probably carbonized material, as residue). Proteases had absolutely no effect on the yellow (body) image or pale yellow non-image fibrils of the Shroud. Protease treatment had no effect on the birefringent red particulates coating fibrils. This further confirms that these birefringent red particulates are definitely different from those in the blood areas and, also, demonstrates that they are not cemented to their fibrils with a protein binder. Further, in our opinion, the totality of these tests does confirm the blood image areas as blood. The question as to whether or not the blood is human blood is best left to future immunologic testing.

A summary of the protein tests employable is shown in Table 4. Table 5 summarizes the tests indicating the presence of blood on the Shroud.

Tests for metallic species - The methods employed in testing for specific metal ions ${ }^{27,47-50}$ are given in Table 6 . While an individual test may be equivocal, the tests taken in combination enable positive identification of the presence of major elements above a level that could produce a colored image evident to the eye. It should also be noted that while all the particulates present are soluble in aqua regia, none is soluble in $8 \mathrm{~N} \mathrm{KOH}$. Thus the presence of such alkali soluble pigments as realgar (AsS), orpiment $\left(\mathrm{As}_{2} \mathrm{~S}_{3}\right)$ and litharge $(\mathrm{PbO})$ are immediately excluded on the basis of solubility.

The uncoated fibrils (non-image, image, and water stain) all give relatively strong positive tests only for $\mathrm{Ca}$ and $\mathrm{Fe}$, except for those from the inside of the water stains which give somewhat weaker, though still definite positive reactions. Thus, we find no evidence for any other metallic species on the body image fibrils at a level that would provide color evident to the eye.

It should be noted that no acidic digestion is needed to obtain the above iron tests, demonstrating that this is some form of cellulosic bound iron on the fibril surface. Such cellulosic bound iron is probably a chelated covalent form held by the aldehyde and carboxylic groups of the partially oxidized cellulose structure (see below, section on preparation of flax). The orange and brown globs also give weak tests for iron, but only after digestion with aqua regia as would be expected for blood derived materials (a strong oxidant is required to liberate the iron from heme ${ }^{14}$ ). The red shards, which contain more hemeprotein, when similarly digested give stronger tests than the globs, but weaker than the fibrils, as would be expected since their color comes from the porphyrin moiety and not their iron content which is relatively small, ${ }^{14,} 33$ The birefringent red coated fibrils give the strongest test of all. Thus, fibrils themselves contain more iron than the isolated blood particulates showing that a great deal of cellulosic bound iron is present on the Shroud. Positive iron tests can also be obtained on the birefringent red particulates by treatment with cold concentrated $\mathrm{HCl}$ in which they 
slowly dissolve. This indicates that the birefringent red particulates are not heme iron which would require a strong oxidant to liberate its iron. A consistent explanation for the interpretation of all these results is that while non-birefringent red particulates are heme containing materials, the birefringent red particles are $\mathrm{Fe}_{2} \mathrm{O}_{3}$ by both chemical and microscopic tests. ${ }^{21,22}$ Digestion of about 50 birefringent red coated fibrils concomitantly, with aqua regia and subsequent testing specifically for trace $\mathrm{Mn}, \mathrm{Co}, \mathrm{Ni}$, and $\mathrm{Al}$ established that such impurities could only be present at a level of less than $1 \%$. Chemically and microscopically, therefore, these birefringent red particles appear to be $\mathrm{Fe}_{2} \mathrm{O}_{3}$ and are quite pure by the chemical tests employed.

Thus we find three types of iron on the Shroud:

a) a cellulose bound chelated form

b) heme bound forms

c) iron oxide $\left(\mathrm{Fe}_{2} \mathrm{O}_{3}\right)$

The predominant form is the cellulose bound form. We have been able to identify $\mathrm{Fe}_{2} \mathrm{O}_{3}$ primarily in the water stain margins and charred blood areas indicating that it only constitutes a very small percentage of the total iron forms found on the Shroud.

The black particles from the scorch areas after aqua regia digestion give strong positive tests only for Ag. Control tests establish, though, that traces of $\mathrm{Hg}, \mathrm{Pb}$, or $\mathrm{Cd}$ could be present as impurities below the level of $1 \%$. No other trace metals are indicated by the tests, however. Silver was not seen by X-ray fluorescence in the scorch areas or other areas of the Shroud, ${ }^{15}$ indicating that it could only be present in quantities below the level of M-series detection, i.e., trace amounts only. This is in agreement with our findings, therefore, as we see it only as an "occasional" specimen and only in scorch areas.

During the microscopic survey of the slides, we noted one large prismatic hexagonal object $(150 \times 50 \mu \mathrm{m})$ on the edge of the tape but in the adhesive on tape sample 6BF. This fractured and we obtained one large $(130 \times 100 \times 10 \mu \mathrm{m})$ deep crimson rhombohedral shaped plate. When excised and digested with aqua regia, this object gave a very strong positive test for $\mathrm{Hg}$ and tested negatively for other metals. On the basis of the optical appearance ${ }^{51}$ and the chemical behavior, this can be identified as "cinnabar" (HgS). Fragments of this particle were found in the same area along a definite track, the exact width of the base of the prismatic hexagonal object. This is clearly an "accidental" artifact as we have seen nothing like it on any other slides, nor have any other red particulates even from this same tape away from this track given a positive test for $\mathrm{Hg}$.

The results of these metal tests are in agreement with the general conclusions reached by Xray fluorescence ${ }^{13}$ which found only in $\mathrm{Ca}, \mathrm{Fe}$ and $\mathrm{Sr}$ on the Shroud above trace levels. However, the chemical testing allows us to be much more specific in the assignment of actual structures of the metallic compounds present. These results do not support the hypothesis that the image is painted with inorganic pigments. 
Tests for organic species and functional groups - The methods employed in testing for specific organic structures and functional groups of possible interest ${ }^{14,34,42,52-56}$ are given in Table 7. These tests were performed on the uncoated fibrils: body image, non-image and scorch fibrils. With the exception of positive aldehyde and cellulosic carboxyl tests, all other species tested for tested negatively. Thus we see no evidence for stains or dyes on the body image fibrils at levels that would be evident to the eye. The fibrils all stain strongly with the Schiff reagent and with methylene blue or toluidine blue O. ${ }^{54,56}$ Note that the amido black and Coomassie Blue reactions mentioned above occur, as they also represent the binding of such basic dyes to these cellulosic carboxyls ${ }^{56}$ in a manner similar to the methylene blue reaction. This further confirms the presence of such cellulosic carboxyl groups. However, if tested side by side the fibrils can be seen to form a progression with pale yellow fibrils (non-image) staining the weakest, the dark fibrils (scorch) staining the strongest, and the yellow fibrils (body image) giving an intermediate reaction. This is the same order as seen in the progressively corroded appearance of their surfaces under observation by phase contrast microscopy (cf., Table 2). It will be shown below that these results can be accounted for by dehydrative oxidation of the cellulosic structure. ${ }^{53}$

It should be noted that although all of the other organic tests are negative, this does not preclude the possibility that some of these substances may have resided on the cloth in the past and been "lost" over time through oxidation, degradation, etc. For example, the possible presence of fats or oils was checked with the standard Harms' and Wij's ${ }^{57,58}$ iodine addition reagents (IBr, ICI). It was found that dilute solutions of such addition reagents were not discharged by the yellow fibrils, showing that unsaturated fatty acids are not now present on the fibrils. This does not preclude their possible past occurrence and loss through slow peroxidation. This would also apply to trace amounts of Saponaria. This simply demonstrates that positive tests in some cases would have been more meaningful than the negative tests.

All known organic dyes and/or stains, both natural and synthetic, act as either acid-base indicators or redox indicators, or can be extracted by some solvent. ${ }^{59-63}$ Therefore, such behavior also constitutes a basis for testing. The "color" of the yellow body image fibrils is neither altered nor extracted by methanol, ethanol, benzene, toluene, acetone, carbon tetrachloride, chloroform, pyridine, ethyl acetate, dimethyl formamide, cyclohexane, ether, morpholine, dioxane, or water. Further, the color is unaffected by either concentrated $\mathrm{HCl}$, concentrated $\mathrm{NH}_{4} \mathrm{OH}$, or $8 \mathrm{~N} \mathrm{KOH}$.

Concentrated $\mathrm{H}_{2} \mathrm{SO}_{4}$ does not extract any color from the yellow image fibrils. However, it readily did so for any of the dyed synthetics found as incidentals on the Shroud and from the brown Coptic and Pharaonic controls. This test has been used extensively in studying ancient dyed textiles. ${ }^{64}$ It does, however, deepen the yellow color of image fibrils over about a half hour. In fact, we found that we could prepare "yellow" fibrils identical in all chemical and microscopic characteristics to those found on the Shroud by treatment of the Spanish linen fibrils with concentrated $\mathrm{H}_{2} \mathrm{SO}_{4}$ for half an hour. The extraction test solvents employed are summarized in Table 8. 
Neutral Superoxyl $\left(30 \% \mathrm{H}_{2} \mathrm{O}_{2}\right)$ does not bleach the yellow color from the Shroud fibrils, even in the presence of UV irradiation, nor do weak reductants such as ascorbate. However, hydrazine bleaches the yellow body image fibril color very slowly and diimide, ${ }^{65,66}$ a very powerful reducing agent, bleaches it instantly. Alkaline peroxide, a very powerful oxidizing agent, similarly bleaches ${ }^{28}$ the yellow body image fibril color quickly. Thus the solvent, redox, and acid-base tests are also consistent with the lack of any applied stains or dyes, but are consistent with the chemistry of carbony groups as a chromophore.

These results are like the metal tests, consistent with previously reported spectroscopic studies on the Shroud ${ }^{11-13}$ which also found no evidence for the presence of dyes or stains. However, again, the chemical studies permit us to be more specific in postulating chromophores, which appear to be integral to the cellulosic structure itself.

\section{Discussion}

The heme derivative and protein work reported here confirms our earlier study. ${ }^{14}$ However, the indication of bile pigments and serum type proteins, i.e., albumin, allows one to form the opinion that it is, in fact, whole blood on the cloth and not just heme protein. Further, the observations that non-heme proteins can be detected in border areas adjacent to blood images supports Barbet's contention ${ }^{5}$ that these blood images generally represent clotted blood and not free blood flows. These conclusions are further supported by the UV photographic studies ${ }^{67}$ which show "serum" halo effects about the scourge marks and at the margins of blood clots. That such a chemically and anatomically correct representation could have been produced by any means other than direct contact of the cloth with a wounded human body is difficult to conceive. The detail in the "scourge" marks as revealed in the fluorescence photography also supports this suggestion of intimate contact. ${ }^{67}$

The presence of several occasional particles of Ag species only in the scorch areas can be readily accounted for. As noted above, the silver casket in which the Shroud was kept at the time of the 1532 fire became hot enough to melt partially. ${ }^{4}$ In fact, the scorches are attributed to burns from this molten silver falling on the folded cloth, forming the scorch pattern now observed. We can safely assume that these silver artifacts are simply residue from this historically recorded event.

While the detection of "cinnabar" might be construed as evidence of the presence of paint pigments, e.g., vermillion, we note that only a single instance of this material has been detected in any of our samples and we therefore consider it incidental. Further, the X-ray fluorescence studies" do not show Hg in the body image areas. It has already been observed that the Shroud has been copied by artists on several occasions, e.g., Reuben and Van Dyke.6, 7, 18 Therefore, the presence of such occasional "accidental" artifacts indicating artists pigments $^{18}$ is not unexpected. To conclude that any of the images were produced by the application of such pigments, they must be shown to be predominantly present and in the appropriate locations. This cinnabar particle was detected in a blood area and more than sufficient evidence has now been presented to establish that these 
images were formed by real blood and are therefore not composed of "vermillion". Our microchemical tests do not reveal $\mathrm{Hg}$ to be present in these areas generally at levels that could be evident to the eye.

We found the calcium to be uniformly distributed over the tape-sampled Shroud areas, while the iron, though also ubiquitous, was enhanced in the blood image areas and concentrated in the margins of the ,water stains. This is consistent with the X-ray study ${ }^{15}$ which showed a uniform concentration of the iron in the image and non-image areas, but enhancement in the areas of blood marks. X-ray fluorescence studies of the water stain margins also show $\mathrm{Fe}$ is concentrated here. Further, the margins are clearly discernible in the X-ray photo-image of the Shroud, although the body image itself is not.

As noted above the chemistry reveals that three types of iron are present: heme bound iron in blood materials, cellulose bound chelated iron found ubiquitously and more or less uniformly over the whole Shroud, and iron oxide particulates mainly, but not exclusively, concentrated in the water stain margins and in some of the scorched areas especially adjacent to blood.

The enhancement of observed total iron and heme iron in the "blood" image areas and the presence of $\mathrm{Fe}_{2} \mathrm{O}_{3}$ in the scorch areas (especially near "blood") are readily explained. The charring of blood to iron oxide was first observed (but not identified as such) by Boyle in $1684 .{ }^{68}$

However, the cellulose bound iron and the water stain margin $\mathrm{Fe}_{2} \mathrm{O}_{3}$ must now be accounted for. It should be recalled that both of these types of iron were quite pure, definitely free of trace $\mathrm{Mn}, \mathrm{Co}, \mathrm{Ni}$, and $\mathrm{Al}$ to below the level of $1 \%$. The geochemistry of iron ${ }^{69,70}$ is such that to find an iron earth pigment as pure as this would be most unusual unless pure hematite were used. In fact, even fairly recent European artist's iron pigments contain either $\mathrm{Mn}, \mathrm{Ni}, \mathrm{Co}$, or $\mathrm{Al}$ above the $1 \%$ leve $1 .{ }^{69,}{ }^{71}$ However, artists of the middle ages reportedly did prepare and use quite pure iron oxide pigments, ${ }^{72}$ although they undoubtedly had typical contaminants below their ability to detect them. Professor L. Riggi* has examined Shroud particles with electron microprobe and finds strong iron signals but not the expected impurity signals for mineralogically derived material. However, when he examines specimens of new and old "Venetian" red, the expected contaminants of other elements such as $\mathrm{Mn}, \mathrm{Co}, \mathrm{Ni}$ and $\mathrm{Al}$ are clearly seen. While the possibility exists that such "pigment" iron might account for some of the $\mathrm{Fe}_{2} \mathrm{O}_{3}$ observations, it cannot account for cellulose bound iron. Fortunately, simpler and more reasonable explanations than accepting a painting process exist.

In the process of converting flax to linen, the material was "retted", i.e., fermented, a practice which required submerging the material in natural bodies of water for extended periods of time. This process was employed up until quite recent times. ${ }^{30,31,73,74}$ During this process the natural ion exchange properties of cellulose operate and two ions found commonly in natural waters that most strongly bind in this way are $\mathrm{Ca}$ and $\mathrm{Fe}$, with the former being more strongly bound, ${ }^{75,76}$ as reflected in the relative concentrations seen in the X-ray and present

* "L. Riggi" is indubitably a misprint for Giovanni Riggi. (Ed.) 
studies. Iron found deposited on linen this way is quite common and offers a very simple explanation of our finding for the cellulose bound iron not only on the Shroud linen but on the samples of Spanish, Coptic and Pharaonic linens. In fact, linen makers are specifically enjoined against using ferruginous waters for retting as it will stain the cloth. ${ }^{30,73,74}$ The same argument accounts for the calcium and, also, for the $\mathrm{Sr}^{75,76}$ seen in the X-ray studies ${ }^{15}$ and is therefore self-consistent.

At the time of the extinguishing of the 1532 fire, ${ }^{4}$ it is reasonable to conceive of this cellulose bound iron "chromatographing" to the water stain margins either as "free" iron or bound to the low molecular weight water soluble degraded cellulosics present, where it could precipitate as $\mathrm{Fe}(\mathrm{OH})_{3}$. By a process similar to the "khaki" process we have described above, it could then produce in time the birefringent red particulate coated fibrils seen. Alternatively, the water used in extinguishing the fire could have been high in its iron content and would produce the same result by a similar migration process. We observed that the Spanish linen "khaki" controls are microscopically and chemically identical to the birefringent red particulate coated fibrils. This includes the fact that some of these particles can be seen in the lumen or core of the fibril as seen on the Shroud. Since many of these internal particles on the Shroud are found between intact joints of the linen fibril, it is difficult to conceive of any way they could have gotten there except by a precipitation process similar to the "khaki" process which we have postulated.

In view of the range of our chemical testing for metal pigments and organic stains and dyes, we found no evidence for the application of any such known materials ${ }^{59-64}$ on this cloth. Whatever the image is due to, it would appear most unlikely that it has been painted as we normally speak of such a process.

It has been observed that cellulose can be oxidized in two ways ${ }^{77,78}$ one producing a "reducing" cellulose (with both aldehyde and carboxyl groups formed) and the other producing a "methylene blue" type cellulose (with carboxyl groups formed exclusively). The latter type is produced by alkaline oxidizing conditions or by ionizing radiation. The former is produced by acid oxidizing conditions (cf., above $\mathrm{H}_{2} \mathrm{SO} 4$ production of a "pseudo-shroud" fibril) or by pyrolytic conditions. This last process is favored by dehydrative conditions and produces a variety of anhydro and unsaturated cellulose derivatives ${ }^{79}$ Therefore, it is seen that the image fibrils are simply more dehydratively oxidized than the non-image fibrils, but less than the scorch fibrils. This provides a consistent explanation of our observations.

It would appear that some type of conjugated carbonyl structure is the most likely chromophore. Its R-bands (315-350 nm) would provide a wave length maximum and extinctions $^{80}$ of the type observed in the UV spectroscopic studies ${ }^{11,13}$ and would also be consistent with the IR observations. ${ }^{12}$ This would suggest some type of low temperature heating process or a high temperature of extremely short duration (insufficient to produce carbonization) as a mechanism for production of the image. For example, near ambient condition processes involving surface contact with foreign substances (e.g., perspiration, olive oil) acting as local catalysts have reproduced many but not all of the observed characteristics of the Shroud body image. ${ }^{11}$ In particular, while giving the proper chemical and spectroscopic behavior, they do not yield the three dimensional 
quality required. Thus we cannot conceive of a single simple mechanism that will also be consistent with the physical and image analysis ${ }^{9}$ studies.

As McCrone's studies ${ }^{17-19}$ demonstrated the presence of protein, iron oxide, and "vermillion" on the sample tapes, he has concluded the Shroud is a painting, the artist employing the protein as a pigment binder to render the body image with iron oxide and the blood marks with a mixture of iron oxide and vermillion. Although we have also identified these same species on the sample tapes, we have drawn the opposite conclusion. To establish the validity of a painting hypothesis it is necessary, but not sufficient, to identify such materials. One must also demonstrate that they are present in sufficient quantities and in such locations as to account for what is seen. Further, it must be shown that their presence cannot be more simply accounted for by other processes. Still, further, one's conclusions must be in accord with other studies; specifically, in this instance, the physical and image analysis investigations.

Our studies differ in several important regards from McCrone's. As he has not distinguished that there are two types of red particulates present (birefringent and non-birefringent), he has not further distinguished between body image and blood samples, nor has he recognized that there are in fact three types of iron compounds present. His protein test, i.e., amido black, as we have demonstrated is not specific, nor as sensitive or as selective as the tests we have employed. He has demonstrated the presence of $\mathrm{Hg}$ by electron microprobe.

We have in our opinion confirmed that the "blood" is in fact real blood (cf., Table 5) and this is in agreement with spectroscopic ${ }^{11-15}$ and forensics studies. We have shown that the bulk of the iron present on the Shroud is in the cellulosic bound form and shown that it is readily accounted for by a well understood natural process, viz., retting, that the linen of the Shroud must have been subjected to, and that this conclusion is supported by the X-ray data. ${ }^{15} \mathrm{We}$ find the iron in the blood areas behaves as heme bound iron. We find iron oxide concentrated in the water stain margins and it is not bound there by a protein. We have demonstrated that iron is present in all the old linens we have tested and retting is a reasonable explanation for its occurrence there. Our conclusions are not only self-consistent, but agree with the X-ray" and spectroscopic" studies which have shown that "iron-oxide" does not correlate with the visually observed image and cannot account for it.

We have further shown that the body image, in fact, is not produced by any pigments, stains, or dyes and is specifically not accounted for by "age yellowed" protein. Protein is present only in blood and in the halo area around some blood. The image arises from dehydratively oxidized cellulose and can be accounted for, but a specific mechanism cannot be provided (see below). This conclusion is consistent with previous work, ${ }^{9-16}$ in particular the microscopic observations, ${ }^{16}$ that show there is no evidence of cementation of the body image fibrils to one another, no capillarity or penetration of the color below the top surface fibrils on the crowns of the fibers of the weave, no evidence of brush marks, etc.

We have also seen vermillion (in a "blood" area, though a different sample from that where McCrone identified it). We feel that it is more easily explained as evidence that artists have copied the Shroud (an historically verifiable fact ${ }^{6,7,9}$ ) 
and not that an artist has rendered it (a severely disputed historical fact ${ }^{7}$ ). In this regard it is interesting to note that the elements other than $\mathrm{Hg}$ detected by McCrone's analysis, viz., $\mathrm{Na}$, $\mathrm{Mg}, \mathrm{Al}, \mathrm{Si}, \mathrm{P}, \mathrm{S}, \mathrm{Cl}, \mathrm{K}, \mathrm{Ca}, \mathrm{Fe}$ and $\mathrm{Cu}$, are in fact all found in whole blood. ${ }^{81}$ However, it would be a most peculiar minerological assemblage that would provide these elements and not the expected iron earth pigment impurities, i.e., $\mathrm{Mn}$, Co, and Ni. His "particle medium agglomerates" where he has detected these elements are the same as our globs which we have shown contain only low amounts of heme bound iron and no visually detectable amounts of Hg. In this regard it should be noted here that the "red color" seen arises from the porphyrin rings present and not the iron contained therein. ${ }^{14,} 33$ In fact, insertation of iron into a porphyrin lowers its intrinsic extinction. Therefore, the "iron" we see in the globs is at the lower limits of our detection, which would place the "mercury" that McCrone sees at trace levels far below the limits that would provide a visually detectable color evident to the eye. This is entirely consistent with contamination due to the artists who have copied the Shroud.

Finally, any applied pigment is incapable of rendering all of the image characteristics found on this cloth. It is highly improbable that any $14^{\text {th }}$ century artist would produce a "reversed" image or could encode the degree of three dimensional, computer readable information ${ }^{9}$ found in this image and leave no other surviving historical evidence of his evident genius.

It is remarkable how closely all these results were predicted by Rogers prior to the actual investigation of the Shroud. ${ }^{82}$ Until further studies are made, the explanation of the image on this intriguing and controversial relic remains a mystery.

Using a Kevex ISI 100B Energy Dispersive Spectrometer. we have examined 16 different globs and fibrils from blood image, body image, and non-image tape samples. The fibrils all show strong $\mathrm{Ca}$ and Fe signals. The globs all show $\mathrm{Na}, \mathrm{Mg}, \mathrm{Al}, \mathrm{Si}, \mathrm{P}, \mathrm{S}, \mathrm{Cl}, \mathrm{K}, \mathrm{Ca}$, and $\mathrm{Fe}$. Some also show $\mathrm{Cu}$ and $\mathrm{Zn}$. Fibrils and globs from the cinnabar "track" area on 6BF also show Hg. Most importantly, there is no Co, Mn, or Ni detected anywhere and the Hg is only detectable in "track" samples. Similar results were obtained by J. Jackson and W. Ercoline in their SEM studies. These results and the conclusions to be drawn therefrom are identical with those from the microchemistry.

\section{Acknowledgments}

We would like to acknowledge our indebtedness to all our fellow members of the STURP group, but in particular to Dr. Ray Rogers for providing the samples and much penetrating discussion. We are also indebted to Maria Heller for the Spanish linen sample, Dr. Frank Dye for assistance with the phase contrast microscopy, Mr. William Barrett and Mr. William Quinnell for photographic assistance. Dr. Donald Grof and Dr. Robert Berner for geochemical references and comments, Fr. Adam Otterbein for making available to us the extensive materials in the Wuenschel Collection at Esopus, and Vern Miller for supplying the photograph shown in Figure 1. 
Table 1

AREAS OF THE SHROUD OF TURIN SAMPLED

\begin{tabular}{|c|c|}
\hline Identification & $\begin{array}{c}\text { Designation } \\
\text { Code }\end{array}$ \\
\hline 1I B & Scorch area, back (image figure) \\
\hline $1 \mathrm{FH}$ & Patch cloth \\
\hline $2 \mathrm{AF}$ & Knee non-image, front, water stain margin \\
\hline 2BF & Knee body image area, front, water stain margin \\
\hline 2CF & Knee body image area, front, inside water stain \\
\hline $3 \mathrm{AB}$ & Body image area, back, adjacent "lance" wound \\
\hline 3AF & Finger body image area, front \\
\hline 3EF & Wrist blood image area, front \\
\hline 3BB & Body image area, back, water stain margin adjacent blood \\
\hline 3CB & Blood image, back, "lance" blood flow \\
\hline 3BF & Non-image area, front, adjacent hand image \\
\hline 3CF & Scorch area, front, near hand image \\
\hline 3FB & Blood-water stain margin, back \\
\hline $4 \mathrm{~F}$ & Backing cloth, exposed on front corner \\
\hline $4 \mathrm{CB}$ & Scourge blood image, middle back \\
\hline $5 \mathrm{BH}$ & Backing cloth \\
\hline $6 \mathrm{BF}$ & Blood image, front, lance area \\
\hline $6 \mathrm{DF}$ & Body image area, front, near lance area \\
\hline $6 \mathrm{AF}$ & Blood-scorch image margin \\
\hline $9 \mathrm{AF}$ & Head non-image area, inside water stain \\
\hline $9 \mathrm{BF}$ & Head non-image area, water stain margin \\
\hline 9CF & Head non-image area, water stain margin \\
\hline
\end{tabular}


Table 2

CLASSES OF SAMPLE OBJECTS TESTED

\begin{tabular}{|c|c|c|}
\hline Designation & Predominant Locations & Comments \\
\hline 1) Very pale fibrils & Backing cloth, patch cloth samples & $\begin{array}{l}\text { Appear very smooth surfaced under phase } \\
\text { contrast }\end{array}$ \\
\hline 2) Pale yellow fibrils & Non-image areas & $\begin{array}{l}\text { Surfaces appear slightly corroded under } \\
\text { phase contrast }\end{array}$ \\
\hline 3) Yellow fibrils & Body image (non-blood) areas & $\begin{array}{l}\text { Surfaces appear corroded under phase } \\
\text { contrast }\end{array}$ \\
\hline 4) Dark fibrils & Scorch areas & $\begin{array}{l}\text { Surfaces appear very corroded under phase } \\
\text { contrast, color varies from light to dark } \\
\text { brown }\end{array}$ \\
\hline 5) Red coated fibrils & Blood areas & $\begin{array}{l}\text { Coating varies from smooth to fractured to } \\
\text { particulate appearance, color varies from red } \\
\text { to orange, coating not birefringent or } \\
\text { pleochroic }\end{array}$ \\
\hline 6) Golden yellow coated fibrils & Margins of blood areas & $\begin{array}{l}\text { Except for color, same general } \\
\text { characteristics as previous, 5) }\end{array}$ \\
\hline 7) Birefringent red particulate coated fibrils & Water stain margins and blood scorch areas & $\begin{array}{l}\text { Color varies from deep red to dark brown; } \\
\text { particulates birefringent and pleochroic; } \\
\text { phase shows some of them inside the hollow } \\
\text { core or lumen of the fibril }\end{array}$ \\
\hline 8) Shards & Blood areas and areas adjacent blood & $\begin{array}{l}\text { Fractured "replica" coatings from red coated } \\
\text { fibrils, not birefringent or pleochroic, } \\
\text { mostly red colored, but olive brown near } \\
\text { scorch areas }\end{array}$ \\
\hline 9) Orange globs & Blood areas and areas adjacent blood & $\begin{array}{l}\text { Color varies from red-orange to orange- } \\
\text { yellow, not birefringent or pleochroic }\end{array}$ \\
\hline 10) Brown globs & Blood-scorch margins & $\begin{array}{l}\text { Appear to be scorched versions of the } \\
\text { previous, but with small, dark particulates } \\
\text { embedded therein }\end{array}$ \\
\hline 11) Black particulates & Scorch areas & Irregular, opaque particles \\
\hline
\end{tabular}


Table 3

SPECIFIC SPANISH LINEN CONTROLS

\begin{tabular}{|c|c|c|}
\hline \multicolumn{2}{|r|}{ Treatment } & Comments \\
\hline 1) & a) Untreated & $\begin{array}{l}\text { Appears similar to Shroud pale yellow fibrils on microscopic } \\
\text { examination }\end{array}$ \\
\hline & b) Above, heated at $100^{\circ} \mathrm{C}$ for 1 hour & $\begin{array}{l}\text { Show very light scorching, structures of fibrils appear more yellow } \\
\text { and more corroded under phase contrast }\end{array}$ \\
\hline & c) Above, heated at $250^{\circ} \mathrm{C}$ for $1 / 2$ hour & Scorched, microscopic appearance similar to Shroud scorch fibrils \\
\hline 2) & a) Saturated with $0.1 \%$ gelatin solution & $\begin{array}{l}\text { Appearance similar to Shroud golden yellow coated fibrils; fibrils } \\
\text { frequently seen cemented together }\end{array}$ \\
\hline & b) Above, heated at $100^{\circ} \mathrm{C}$ for 1 hour & Less scorched than untreated fibril \\
\hline & c) Above, heated at $250^{\circ} \mathrm{C}$ for $1 / 2$ hour & Less scorched than untreated fibril \\
\hline $\begin{array}{l}\text { 3) } \\
\text { (jew }\end{array}$ & $\begin{array}{l}\text { a) Saturated with sonerated } 0.1 \% \text { gelatin and } 0.1 \% \mathrm{Fe}_{2} \mathrm{O}_{3} \\
\text { eler's rouge, approximately } 1 \mu \mathrm{m} \text { diameter) }\end{array}$ & $\begin{array}{l}\mathrm{Fe}_{2} \mathrm{O}_{3} \text { particles frequently clumped as well as adherent to fibrils, } \\
\text { resembles birefringent red particulate Shroud fibrils more closely } \\
\text { than the non-birefringent red coated fibrils under phase contrast; no } \\
\text { internal particles seen in the lumen of the fibrils }\end{array}$ \\
\hline & b) Above, heated at $100^{\circ} \mathrm{C}$ for 1 hour & Clumps tend to break apart, leaving separate fine $\mathrm{Fe}_{2} \mathrm{O}_{3}$ particles \\
\hline & c) Above, heated at $250^{\circ} \mathrm{C}$ for $1 / 2$ hour & $\mathrm{Fe}_{2} \mathrm{O}_{3}$ particles tend to darken to browner shade \\
\hline 4) & a) Saturated with whole blood (2 year old human) & Closely resembles Shroud red coated fibrils, except redder colors \\
\hline & b) Above, heated at $100^{\circ} \mathrm{C}$ for 1 hour & $\begin{array}{l}\text { More closely resembles Shroud red coated fibrils microscopically in } \\
\text { color and polarization properties }\end{array}$ \\
\hline & c) Above, heated at $250^{\circ} \mathrm{C}$ for $1 / 2$ hour & $\begin{array}{l}\text { Scorched, some areas similar to Shroud brown globs, others slightly } \\
\text { resemble the birefringent red particulate coated fibrils in } \\
\text { microscopic properties }\end{array}$ \\
\hline $\begin{array}{l}\text { 5) } \\
\text { twic }\end{array}$ & $\begin{array}{l}\text { a) Saturated with Saponaria extract for } 1 \text { hour, then rinsed } \\
\text { e with distilled water }\end{array}$ & $\begin{array}{l}\text { Resembles Shroud pale yellow fibrils, shows pale yellow-green } \\
\text { fluorescence under short wave UV }\end{array}$ \\
\hline & b) Above, heated at $100^{\circ} \mathrm{C}$ for 1 hour & $\begin{array}{l}\text { Scorched, more heavily than untreated, now shows pale orange } \\
\text { fluorescence under short wave UV }\end{array}$ \\
\hline & c) Above, heated at $250^{\circ} \mathrm{C}$ for 1 hour & $\begin{array}{l}\text { Heavily scorched, charred in places, fluorescence about same as } \\
\text { previous sample }\end{array}$ \\
\hline 6) & a) Khaki (cf. text), air dried & $\begin{array}{l}\text { Visually similar to red coated fibrils, but birefringent and } \\
\text { pleochroic; some particles seen inside lumen }\end{array}$ \\
\hline & b) Above, heated at $100^{\circ} \mathrm{C}$ for 1 hour & $\begin{array}{l}\text { Closely resembles Shroud birefringent red particulate coated fibrils } \\
\text { in all microscopic properties }\end{array}$ \\
\hline & c) Above, heated at $250^{\circ} \mathrm{C}$ for $1 / 2$ hour & Scorches, particles darken to very dark brown \\
\hline
\end{tabular}


Table 4

TESTS EMPLOYABLE FOR THE DETECTION OF PROTEINS

\begin{tabular}{l|l}
\hline \multicolumn{1}{c|}{ Reagent } & \\
\hline Ninhydrin & Interferences under our conditions preclude use of this test \\
Amido Black & Also stains cellulosic carboxyls, therefore not specific enough \\
$\begin{array}{l}\text { Coomassie Brilliant Blue } \\
\text { Bromthymol Blue }\end{array}$ & $\begin{array}{l}\text { Same caveat as for Amido Black } \\
\text { Biuret-Lowry }\end{array}$ \\
Bromcresol Green & Same caveat as for Bromthymol Blue, but selective for peptides \\
Fluorescamine & Metachromatic, only relatively sensitive, but selective for albumin \\
Proteases & Fluorimetric test, very sensitive, specific for primary amines \\
\hline
\end{tabular}

Table 5

TESTS CONFIRMING THE PRESENCE OF WHOLE BLOOD ON THE SHROUD

1) High Fe in blood areas by X-ray fluorescence

2) Indicative reflection spectra

3) Indicative microspectrophotometric transmission spectra

4) Chemical generation of characteristic porphyrin fluorescence

5) Positive hemochromagen tests

6) Positive cyanmethemoglobin tests

7) Positive detection of bile pigments

8) Positive demonstration of protein

9) Positive indication of albumin specifically

10) Protease tests, leaving no residues

11) Microscopic appearance as compared with appropriate controls

12) Forensic judgement of the appearance of the various wound and blood marks 
Table 6

TESTS EMPLOYED FOR DETECTION OF METALLIC SPECIES

\begin{tabular}{|c|c|c|}
\hline Element & Method & (Reference), page \\
\hline $\mathrm{Fe}$ & $\begin{array}{l}\text { 1) Mg Bathophenathroline } \\
\text { b) } 3 \text { - (4-phenyl-2 pyridyl)-5 phenyl-1,2,4 - } \\
\text { triazine disulfonic acid, disodium salt } \\
\text { (PPTS) }\end{array}$ & $\begin{array}{l}(34), 924 ;(47) \\
(48)\end{array}$ \\
\hline $\mathrm{Ca}$ & $\begin{array}{l}\text { a) o - cresolpthalein complexone } \\
\text { b) glyoxal bis (2-hydroxyanil) }\end{array}$ & $\begin{array}{l}\text { (49) } \\
\text { (327), 534-535 }\end{array}$ \\
\hline $\mathrm{Cu}$ & $\begin{array}{l}\text { a) Neocuproine } \\
\text { b) Cuprizone }\end{array}$ & $\begin{array}{l}(50) \\
(50)\end{array}$ \\
\hline Mn & $\mathrm{Ag}+$ and catalyzed acid persulfate & (27), 173 \\
\hline Ni (Pd) & a) dimethyl glyoxime & (27), 149-153 \\
\hline (Co) & b) Nioxime & (27), $149-153$ \\
\hline Co & Ammonium thiocyanate - fluoride & (27), 146-147 \\
\hline $\mathrm{Al}$ & $\begin{array}{l}\text { a) Aluminon } \\
\text { b) alizarin }\end{array}$ & $\begin{array}{l}\text { (27), } 191 \\
\text { (287), 185-188 }\end{array}$ \\
\hline $\mathrm{Zn}(\mathrm{Hg})$ & $\begin{array}{l}\text { a) dithizone } \\
\text { b) Zincon }\end{array}$ & $\begin{array}{l}\text { (27), } 178-180 \\
\text { (27), } 178-180\end{array}$ \\
\hline $\mathrm{Ag}(\mathrm{Hg})$ & p-dimethylaminobenzalrhodanine & (27), 59-61 \\
\hline $\mathrm{Hg}(\mathrm{Cd})$ & $\begin{array}{l}\text { a) Biphenyl carbazone } \\
\text { b) dithizone }\end{array}$ & $\begin{array}{l}\text { (27), 64-65 } \\
\text { (27), 71-72 }\end{array}$ \\
\hline $\mathrm{Pb}$ & $\begin{array}{l}\text { a) dithizone } \\
\text { b) sodium rhodizonate }\end{array}$ & $\begin{array}{l}\text { (27), 74-75 } \\
\text { (27), 73-74 }\end{array}$ \\
\hline As & stannous chloride & (27), 99-100 \\
\hline $\mathrm{Sb}$ & rhodamine B & (27), $105-107$ \\
\hline Sn & phosphomolybdate & (27), 108-109 \\
\hline $\mathrm{Cr}$ & diphenylcarbazone - persulfate & (27), 170 \\
\hline
\end{tabular}


Table 7

TESTS EMPLOYED FOR THE DETECTION OF ORGANIC STRUCTURES

AND FUNCTIONAL GROUPS

\begin{tabular}{|c|c|c|}
\hline Species & Method & $\begin{array}{l}\text { (Reference), } \\
\text { Page }\end{array}$ \\
\hline phenols & $\begin{array}{l}\text { a) nitrous acid } \\
\text { b) ferric ion }\end{array}$ & $\begin{array}{l}\text { (42), } 179-181 \\
(34), 1147-1148\end{array}$ \\
\hline riboflavin & $\begin{array}{l}\text { a) UV fluorescence, } \\
\mathrm{H}_{2} \mathrm{O}_{2} \text { quenched }\end{array}$ & (34), 559 \\
\hline steroids & $\begin{array}{l}\text { a) Lieberman - Burchard } \\
\text { b) Salkowski }\end{array}$ & $\begin{array}{l}\text { (34), } 507-514 \\
\text { (34), } 507-514\end{array}$ \\
\hline indoles & $\begin{array}{l}\text { a) glutaconic aldehyde } \\
\text { b) nitrosonaphthol, nitrous acid }\end{array}$ & $\begin{array}{l}\text { (42), 382-383 } \\
\text { (34), 819-821 }\end{array}$ \\
\hline lignin (allyls) & phloroglucinol — $\mathrm{HCl}$ & (52); (42), 169-170 \\
\hline starch & iodine - iodide & (13), 239 \\
\hline porphyries & hydrazine — formic acid & (14) \\
\hline pyrroles. & p-dimethylaminobenzaldehyde & (42), 381-382 \\
\hline creatinine & alkaline picrate & (34), 996-998 \\
\hline uric acid & phosphotungstic acid & (34), 999-1002 \\
\hline urea derivatives & phenylhydrazine & (42), 390 \\
\hline amines, primary & $\begin{array}{l}\text { a) ninhydrin } \\
\text { b) fluorescamine }\end{array}$ & $\begin{array}{l}(38) \\
(46)\end{array}$ \\
\hline nitro derivatives & $\begin{array}{l}\text { a) diphenylamine } \\
\text { b) fast blue salt B }\end{array}$ & $\begin{array}{l}\text { (42), } 295 \\
\text { (42), } 296\end{array}$ \\
\hline aldehydes & Schiff funchin — sulfurous acid & (42), 195-196 \\
\hline carboxyl, cellulosic & $\begin{array}{l}\text { a) methylene blue } \\
\text { b) toluidine blue } O\end{array}$ & $\begin{array}{l}(54) \\
(56)\end{array}$ \\
\hline Saponaria extract & sulfuric acid & cf. Text \\
\hline
\end{tabular}

Table 8

SOLVENTS EMPLOYED IN DYE EXTRACTION TESTS

\begin{tabular}{l|l|l}
\hline methanol & carbon tetrachloride & Cyclohexane \\
\hline & chloroform & Ether \\
ethanol & pyridine & Morpholine \\
benzene & ethyl acetate \\
dimethylforamide & Dioxane \\
acetone & concentrated $\mathrm{NH}_{4} \mathrm{OH}$ & Water \\
concentrated $\mathrm{HCl}_{2}$ & $8 \mathrm{KOH}$ & $30 \% \mathrm{H}_{2} \mathrm{O}_{2}$ \\
concentrated $\mathrm{H}_{2} \mathrm{SO}_{4}$ & & hydrazine \\
\hline
\end{tabular}




\section{REFERENCES}

1. CULLITON, B.J., "The Mystery of the Shroud of Turin Challenges 20th-century Science," Science, Vol. 201, July 21, 1978, pp. 235239.

2. $\quad$ WEAVER, K.F., "The Mystery of the Shroud," National Geographic, Vol. 157, No. 6, June, 1980, pp. 730-753.

3. JOHNSON, R. I, "Scientists Examine the Shroud of Turin," Industrial Research and Development, February 1980, pp. 145-149.

4. WILSON, I., The Shroud of Turin, revised edition. Image Books (a division of Doubleday \& Co., Inc.), Garden City, New York, 1979.

5. BARBET, P., A Doctor at Calvary, translated by the Earl of Wicklow, Image Books, Garden City, New York, 1963.

6. VIGNON, P., The Shroud of Christ, translated from the French, University Books, New Hyde Park, New York, 1970.

7. BULST, W., The Shroud of Turin, translated by S. McKenna and J. J. Galvin (in cooperation with the Holy Shroud Guild, Esopus, New York), The Bruce Publishing Company, Milwaukee, Wisconsin, 1957.

8. STEVENSON, K. (editor), "Proceedings of the 1977 United States Conference on the Shroud of Turin," March 1977, Holy Shroud Guild, 294 East 150 Street, Bronx, New York, 1977.

9. JACKSON, J., JUMPER, E., MOTTERN, R., and STEVENSON, K., "The Three Dimensional Image on Jesus' Burial Cloth," in ref. 8, pp. 74-94.

10. JUMPER, E., and MOTTERN, R., "Scientific Investigation of the Shroud of Turin," Applied Optics, Vol. 19, No. 12, June 1980, pp. 1909-1912.

11. PELLICORI, S., "Spectral Properties of the Shroud of Turin," Applied Optics, Vol. 19, No. 12, June 1980, pp. 1913-1920.

12. ACCETTA, J., and BAUMGART, J. S., "Infrared Reflective Spectroscopy and Thermographic Investigations of the Shroud of Turin," Applied Optics, Vol. 19, No. 12, June 1980, pp. 1921-1929.

13. GILBERT, R, and GILBERT, M., "Ultraviolet-Visible Reflectance and Fluorescence Spectra of the Shroud of Turin," Applied Optics, Vol. 19, No. 12, June, 1980, pp. 19301936.

14. HELLER, J., and ADLER, A., "Blood on the Shroud of Turin," Applied Optics, Vol. 19, No. 16, August 1980, pp. 2742-2744.

15. MORRIS, R., SCHWALBE, L., and LONDON, J., "X-ray Fluorescence Investigation of the Shroud of Turin," X-ray Spectrometry, Vol. 9, 1980, pp. 40-47.

16. PELLICORI, S., and EVANS, M., "The Shroud of Turin through the Microscope," Archaeology, Vol. 34, No. 1, January 1981, pp. 3443.

17. MCCRONE, W., and SKIRIUS, C., "Light Microscopical Study of the Turin 'Shroud' I," The Microscope, Vol. 28, No. 3, 1980, pp. 105-113 (available from the McCrone Research Institute, 2820 South Michigan Ave, Chicago, Illinois, 60616).

18. MCCRONE, W. "Light Microscopical Study of the Turin 'Shroud' II," The Microscope, Vol. 28, No. 4, 1980, pp. 115-128.

19. McCRONE, W., "Microscopical Study of the Turin 'Shroud' III," The Microscope, Vol. 29, 1981, pp. 19-38.

20. SCHAEFFER, H., Microscopy for Chemists, Dover Publications, New York, N.Y., 1966.

21. WINCHELL, A., and WINCHELl, M., Elements of Optical Mineralogy, Part I. Principles, 4th edition, John Wiley \& Sons, New York, N.Y., 1951.

22. WINCHELL, A., and WINCHELL, H., Elements of Optical Mineralogy Part II. Descriptions of Minerals, John Wiley \& Sons, New York, N.Y., 1951.

23. BLOSS, F. D., An Introduction to the Methods of Optical Crystallography, Holt, Rinehart, and Winston, New York, N.Y., 1961.

24. CHAMOT, E., and MASON, C., Handbook of Chemical Microscopy, Vol. I, $2^{\text {nd }}$ edition, John Wiley \& Sons, New York, N.Y., 1940. 
25. KIRK, P., Quantitative Ultramicro-analysis, John Wiley \& Sons, New York, N.Y., 1950.

26. KIRK, P., Crime Investigation, $2^{\text {nd }}$ edition, edited by J. Thorton, John Wiley \& Sons, New York, N.Y., 1974.

27. FIEGL, F., Spot Tests In Inorganic Analysis, $5^{\text {th }}$ edition, translated by R. Oesper, Elsevier Publishing Company, Amsterdam, Netherlands, 1958.

28. HIBBERT, E., "Bleaching," Encylopaedia Britannica, Vol. 3, 13th edition, Encyclopaedia Britannica, Chicago, Illinois, 1955, pp. 711716.

29. PETERSON, R., and MCKENNY, W., A Field Guide to Wildflowers of Northeastern and Northcentral North America, Houghton Mifflin Co., Boston, Massachusetts, 1968, pg. 266.

30. BENDURE, Z., and PFEIFFER, G., America's Fabrics, Macmillan Company, New York, N Y, 1946.

31. MARSH, J., Textile Science, Chapman and Hall, London, England, 1949.

32. In ref. 31, pg. 379.

33. LEMBERG, R., and LEGGE, J., Hematin Compounds and Bile Pigments, Interscience Publishers ,New York, N.Y., 1949.

34. TIETZ, N., Fundamentals of Clinical Chemistry, 2nd edition, W.B. Saunders, Philadelphia, PA, 1976.

35. In ref. 34, pp. 1036-1038.

36. JENDRASSIK, L., and GROF, P., "Simplified Photometric Methods for the Determination of the Blood Bilirubin," Biochemische Zeitschrift, Vol. 297, 1938, pp. 81-89.

37. MCDONAGH, A., "Bile Pigments," The Porphyrins, Vol. VI, edited by D. Dolphin, Academic Press, New York, N.Y., 1978, pp. 294472.

38. In ref. 34, pp. 378-379.

39. WILSON, C., "Polycrylamide Gel Electrophoresis of Protein," Analytical Biochemistry, Vol. 53, No. 2, 1973, pp. 538-545.

40. MARTIN, E., "Some Improvements in Techniques of Analysis of Paint Media," Studies in Conservation, Vol. 22, 1977, pp. 63-67.

41. FAIRBANKS, G., STECK, T., and WALLACH, D., "Electrophoretic Analysis of the Major Polypeptides of the Human Erythrocyte Membrane," Biochemistry, Vol. 10, No. 13, June 1971, pp. 2606-2617.

42. FIEGL, F., and ANGER, V., Spot Tests in Organic Chemistry, 7th edition, translated by R. Oesper, Elsevier Publishing Company, Amsterdam, Netherlands, 1966.

43. In ref. 42, pp. 370-372.

44. In ref. 34, pp. 302-304 and 354-355.

45. In ref. 34, pp. 336-338.

46. UDENFRIEND, S., STEIN, S., BOHLEN, P., DIARMAN, W., LEIMGRUBER, W., and WEIGE, E, M., "Fluorescamine: Reagent for Assay of Amino Acids, Peptides, Proteins, and Primary Amines in the Picomole Range," Science, Vol. 178, November 1972, pp. 871-872.

47. "Serum Iron / TIBC Test Kit," American Monitor Corp., Box 68505, Indianapolis, Indiana, 1977.

48. McBRIDE, L., The Iron Reagents, 3rd edition, G. Frederick Smith Co., 867 McKinleyAve., Columbus Ohio, 1980.

49. "60 Second Calcium Test Kit," American Monitor Corp., Box 68505, Indianapolis, Indiana, 1977.

50. DIEHL, M., SMITH, G., SCHILT, A., and MCBRIDE, L., The Copper Reagents, $2^{\text {nd }}$ edition, G. Frederick Smith Co., 867 McKinley Ave., Columbus, Ohio, 1977.

51. In ref. 22, pg. 45.

52. GURR, E., A Practical Manual of Medical and Biological Staining Techniques, Interscience Publishers, New York, N.Y., 1953, pg. 203.

53. OTT, E., SPURLIN, H., and GRAfFLIN, M., Cellulose and Cellulose Derivatives, Part I, Interscience Publishers, New York, N.Y., 1954.

54. In ref. 53, pp. 141-142. 
55. PIGMAN, W. (editor), The Carbohydrates, Academic Press, New York, N.Y., 1967.

56. NOGGLE, G., "The Identification and Quantitative Determination of Carbohydrates," in ref. 55, pp. 602-640.

57. MEHLENBACHER, V., The Analisis of Fats and Oils, The Garrard Press, Champaign, Illinois, 1960, pp. 311-330.

58. LEVITT, B., Oils, Detergents and Maintenance Specialities, Vol. I, Chemical Publishing Co., New York, N.Y., 1967, pp. 229-233.

59. THEEL, P., Analytical Methods for a Textile Laboratory, American Association of the Textile Chemists and Colorist, Lowell Textile Institute, Lowell, Mass., 1949.

60. CLAYTON, E., Identification of Dyes on Textile Fibers, $2^{\text {nd }}$ edition, The Society of Dyers and Colourists, Dean House, Piccadilly, England, 1963.

61. BILlMEYER, F., KUMAR, R., and SALTZMAN, M., "Identification of Organic Colorants In Art Objects by Solution Spectrophotometry," Journal of Chemical Education, Vol. 58, No 4, April 1981, pp. 307-313.

62. SEQUIN-FREY, M., "The Chemistry of Plant and Animal Dyes," Journal of Chemical Education, Vol. 58, No. 4, April 1981, pp. 301306.

63. FRIEDSTEIN, M., "A Short History of the Chemistry of Painting," Journal of Chemical Education, Vol. 58, No. 4, April 1981, pp. 291-295.

64. SALTZMAN M., "The Identification of Dyes in Archaeological and Ethnographic Textiles" in Archaeological Chemistry-II, edited by G. Carter, Advances in Chemistry Series, 171, American Chemical Society, Washington D.C., 1978, pp. 172-185.

65. MILLER, C., "Hydrogenation with Diimide," Journal of Chemical Education,Vol. 42, No. 5, 1965, pp. 254-259.

66. HUNIG, S., MULlER, H., and THIER, W., "The Chemistry of Diimine," Angewandte Chemie (International Edition), Vol. 4, 1965, pp. 271280.

67. MILLER, V., and PELLICORI, S., "Ultraviolet Fluorescence Photography of the Shroud of Turin," to appear in Journal of the Biological Photography Association.

68. THOMSON, T., Chemistry of Animal Bodies, Adam and Charles Black, Edinburgh, Scotland, 1843, pp.349-351.

69. MELLOR, LW., A Comprehensive Treatise on Inorganic and Theoretical Chemistry, Vol. XII, Longmans, Green and Co., London, England, 1937, pp. 482-580.

70. MUELLER, R., and BERNER, R., "Iron" in the Handbook of Geochemistry, edited by K. Wedepohl, Vol. 11/2, Chapter 26, SpringerVerlag, Berlin, Germany, 1970, pp. 26-1 to 26-M-6.

71. HURST, G., Printer's Colours, Oils. and Varnishes, $4^{\text {th }}$ edition, Charles Griffin \& Co., London, England, 1906, pp. 240-247.

72. THOMPSON, D., The Materials and Techniques of Medieval Painting, Dover Publications, New York, N.Y., 1956, pp. 97-98.

73. OLNEY, L., Textiles Chemistry and Dyeing, Part I, 10th edition, Lowell Textile Associates, Lowell, Mass., 1947, pp. 54-59.

74. WINGATE, I., Textile Fabrics, V- edition, Prentice-Hall, New York, N.Y., 1949, pp. 107-110.

75. In ref. 53, pp. 209-213.

76. JAHN. E., "The Chemical Behavior of Wood," in Wood Chemistry, edited by L. Wise, ACS monograph 97, Reinhold Publishing Co., New York, 1946, pp. 762-827.

77. In ref. 53, pp. 99-183.

78. BIKALES, N., and SEGAL, L., Cellulose and Cellulose Derivatives, Part V, Wiley — Interscience Publishers, New York, N.Y., 1971.

79. SOWDEN, J., in ref. 55, pp. 367-405.

80. SILVERSTEIN, R., and BASSLER, G., Spectrometric Identification of Organic Compounds, $2^{\text {nd }}$ edition, John Wiley Sr Sons, New York, N.Y., 1967, pp. 158-162.

81. SPECTER, W., Handbook of Biological Data, Saunders and Co., Philadelphia, PA, 1956, pg. 52.

82. ROGERS, R., in ref. 8, pp. 131-135. 